\title{
The Role of the State Sector in the Context of Economic Dependence
}

\author{
by Brian Van Arkadie*
}

I INTRODUCTION

During the past three years (1967-1970), there have been major efforts to expand the role of the State Sector in a number of East and Central African states. The decisions to expand the state sector made in various forms in Tanzania, $Z$ ambia, Uganda and Congo-Kinshasa, were aimed in part to deal with the basic problem of economic dependence.

Following political independence, economic dependence persisted in certain crucial respects. Dependence extended beyond the fact of foreign ownership of certain parts of the economy, although foreign ownership did, in some ways act as a key link in maintaining a dependent economic system. Dependence consisted of reliance on foreign decision-making and foreign resources, and of stunted development of indigenous instituticns. Development of the state sector could both reduce the degree of foreign control and provide the basis for the development of indigenous economic institutions.

Che notable attempt to define an approach to the public sector relevant to the contemporary Third World was made by Ignacy Sachs. He identified two characteristic approaches the "Japanese" approach and the "Indian" approach. Under both patterns the state takes on a crucial role in raising the rate of accumulation and accelerating the rate of growth. "The 'Japanese pattern' consists of large transfers of public funds to the private sector, and of the State performing the so-called 'pioneering functions' in lieu, and on behalf of private capitalists ... The 'Indian pattern' strives at ensuring the primacy of the State in the basic branches

* Brian Van Arkadie is a Fellow of the Institute. This article is a summary of a longer paper, to appear in a volume planned under editorship of Professor D. Ghai. 
of industry and at weakening the concentration of capital ... But even in India elements of the 'Japanese pattern' may be found, side by side with those of the 'Indian pattern'." 11$)$

Sachs' image incorporates a useful framework for considering some of the problems of the public sector in a contemporary developing country. It retains, however, as its central focus the task of accumulation. In the economies we are considering, the problems to be overcome in mobilising development effort can only be understood if the nature of the excessive dependence of these economies is first analysed. Indeed, tackling the problem of economic dependence may well be a prerequisite to the implementation of successful development policies in general, and to sufficiently raising the rate of accumulation in particular.

Although the effects of dependence do manifest themselves in the difficulties of sustaining high levels of capital formation, the dimensions of dependence extend into managerial, technical and entrepreneurial factors, and the existing forms of commodity specialisation are an outcome of the historical pattern of dependence. A formally public institution can easily be the means of continuing dependence on private foreign interests, if it operates as a front for foreign managers, promoters and exploitation by foreign knowhow, and its policies reinforce dependent relationships in commodity markets.

\section{DEPENDENCE}

Economic independence is often recognised by economists as a policy objective, but is viewed as political in origin, non-economic (if not irrational) in character. The pursuit of economic independence is then viewed as one objective which can be traded off against others (e.g. growth). This leaves the underlying neo-classical model intact as a description of optimal growth behaviour.

Yet it seems likely that economic independence, although certainly a national aspiration, is also a necessary condition for the achievement of other development goals.

(1) Ignacy Sachs, Patterns of the Public Sector in underdeveloped Economies, 1963, p.180-181. 
The people of East and Central Africa remain dependent on foreign economic interests because of differentials in:

(a) access to information;

(b) access to managerial skills;

(c) bargaining strength in important commodity markets ;

(d) control of important assets;

(a) claims on income flows.

Items (d) and (e) result from foreign ownership in the domestic economy;

from ownership.

(a), (b) and (c) do not derive primarily

Emphasis is placed on information and management both because the economist's approach typically neglects them, emphasising instead financial and commodity flows, and because technique and managerial capacity are increasingly important elements in modern economic activity.

The condition of dependence is to be analysed not only in terms of flows between economies (e.g. trade and capital movements), but also in terms of the impact on the internal organisation of the dependent economy. Key elements on the dependent side acquiesce in the relationship, or even actively assimilate attitudes supportive of the relationship. To quote Fanon: "The national middle-class discovers its historic mission: that of intermediary."(1)

The structure of production which characterises underdevelopment is we11-known. (2) Under the colonial system, the pattern of development created an economic dependence on primary commodity export markets. The dangers of such a dependence, particularly where a monoproduct system was involved, have been emphasised (possibly over-emphasised) in the literature. However, there are other factors as important as the dangers of over-specialisation in the world commodity market. The form of African participation in this trade was through the supply of labour power as workers or peasants. Where large-scale capital or elaborate technical

(1) F. Fanon, The Wretched of the Earth, New York, 1963, p. 124

(2) This, and many other aspects of African dependence, are summarised in Unity or Poverti,, R.H. Green and A. Seidman, London, 1968, especially pp.31-51 and 91-131. See also R.H. Green, Stages in Economic Development, Bank of Sudan, Khartoum, (no date). 
skills were required, these were under the control of foreign or immigrant interests (e.g. copper in Katanga and Zambia, sisal in Tanzania). Hirschman has stated the problem well:
"The opponents of free trade have often pointed out that for a variety of reasons it is imprudent and harmful for a country to become specialised along certain product lines in accordance with the dictates of comparative advantage. Whatever the merit of these critical arguments, they would certainly acquire overwhelming weight if the question arose whether a country should allow itself to become specialised not just along certain commodity lines, but along factor-of-production lines. Very few countries would ever consciously wish to specialise in unskilled labour, while foreigners with a comparative advantage in entrepreneurship, management, skilled labour and capital took over these functions, replacing inferior 'local talent'." (1)

The economic pattern of dependence, which survived the demise of the political system of colonialism, must be understood as a system, the various parts of which reinforce each other, and the meaning of which is not to be understood by isolating one aspect separate from the whole.

The manifestation of the dependent relationship varied from industry to industry. In copper, foreign control of the industry resulted from ownership, but was also supported by the evident lack of local capacity to organise production. As the product is marketed internationally, control over access to world markets could conceivably be used as an additional means of reinforcing a dominant position.

In the newly-developing manufacturing and tourism sectors, new patterns of dependence are emerging. In industry, local assembly or processing of inputs produced by an investing overseas firm ties the local factory to a particular source of supply and allows that source of supply to reap the benefits of the protected market, although not necessarily through the apparent profit on the local venture. In some instances, projects are promoted from abroad with modest foreign equity involvement, for the purpose of promoting the sale of foreign machinery. In the tourist industry, dependence is associated with a lack of local expertise in the hotel and similar

(1) Albert 0. Hirschman, "How to Divest in Latin America and Why," (p.4), Essays in International Finance, no. 76, November, 1969, Princeton University. 
trades, as well as limited information about available markets. The extension of the operations of multi-national hotel chains and airlines into new areas creates additional foreign control in one of the fastest growing sectors.

The firms which form the agency of external dependence are a mixed bag, ranging from the prototypical multi-national mining firm, through the colonial commercial banking institutions, to smaller-scale trading firms. While it is fitting to place the large, sophisticated multi-national corporation at the centre of an analysis of continuing dependence, (1), there was a range of far more modest businesses which had developed during the colonial period. In some cases, such as the sisal industry of Tanzania, foreign investment played the minor role, local immigrant businessmen owning the larger part of the industry.

The difficulties arising from dependence do not result primarily from reliance on foreign markets. For small economies, a high degree of integration in the world market is unavoidable; autarchy is not a feasible alternative. (However, the small size of African states is itself an outcome of colonial history). Nor is the problem one of reliance on foreign technology, which is inevitable. Rather it is that access to foreign markets, foreign technology and designs, and managerial talents came in a form. in which understanding, access to information, and critical decisions were either controlled elsewhere. Where such local elements did exist they were drawn from the imigrant community.

If ownership were the only dimension of dependence, tackling the problem would be straightforward. Indeed, a degree of foreign ownership by itself causes no great concern in many developed countries. The full significance of foreign ownership can only be appreciated if it is seen as part of the overall structure of dependence, in which ownership patterns are part the cause, but also in part the result, of other dimensions of dependence(2), involving entrepreneurial, technical and managerial elements, as much as reliance on foreign capital, narrowly defined.

(1) Vide Giovani Arrighi, International Corporations, Labour Aristocracies and Economic Development in Tropical Africa, (mimeographed, 1967, Dar-es-Salaam).

(2) It is not necessary, for this analysis, to examine the role of investment and its motivation - the pursuit of profits and markets - as a driving force in imperialism. Whatever the initial impetus at the imperial centre, the condin tion of dependen'ce in the colonial or neo-colonial-periphery pervades all the dimensions of economic and social activity. 
The problem of dependence arose not only because of the presence of foreign economic interests, but also because of the absence of indigenous economic institutions capable of operating effectively in those sectors dominated by them. Where locally based firms achieved substantial size, they grew from the businesses of the immigrant community (the classic case being Madhvani, the successful Ugandan Asian capitalist). Africans were successful farmers, and in particular cases individuals did amass sizeable fortunes from property, cattle-dealing, contracting, etc. However, such African success stories did not give rise to industrial or financial activities in sectors characteristically dominater by large-scale foreign business. (1)

Quite apart from any commitment to socialism, there was an inevitable underlying tension following independence. While African personnel took over the staffing of the civil service, strategic sectors of the economy remained expatriatestaffed, apart from a certain amount of window-dressing, and were certainly controlled by foreign business or immigrant communities.

The existence of such tension was even recently demonstrated in Kenya, where the government has been identified with the most sympathetic policies toward foreign investment in the region. A select Committee of the National Assembly on Unemployment, reporting in 1970, stated that:

"For the Government effectively to exercise control of the economy it must nationalise or acquire effective shareholding in all major enterprises in the economy. ... Side by side with the control of the economy through nationalisation and/or acquisition of majority shareholding in the major enterprise the present

(1) See Peter Marris and Anthony Somerset, African Business men, London, 1970, Chapter 7, and !'Who Controls Industry in Kenya?", Report of a working party of the National Christian Council of Kenya, East African Publishing House, 1968, for the two sides of the coin in Kenya. To quote Marris and Somerset, "Since most of the densely settled parts of Kenya lie within two hundred miles of each other, even perishable goods like bread can be supplied from a few manufacturing centres. An African producer has to compete in a national or international market from the outset. He cannot begin with a small trade in familiar country. As soon as he installs machinery and becomes more than a village cook or craftsman, he faces the uninhibited competition of modern machinery." p.166. 
effects of Kenyanisation should be accelerated."(1)

\section{EXPANSION OF THE STATE SECTOR}

The colonial state had used state corporations for its purposes; the British in Africa were particularly keen on marketing boards. In the case of Uganda, public investment had extended far and wide through the agencies of the Uganda Development Corporation, the Uganda Electricity Board and the marketing boards. In Tanzania, the Development Corporation was, in the first place, mainly a repository for assorted remnants of the groundnuts fiasco, to which was added the lucrative governmental holdings in Williamson's diamond mines. Even in the Congo, there has been a long, if somewhat peculiar, history of public involvement in the copper industry.

Early post-independence Plans placed heavy emphasis on foreign investment, particularly in manufacturing. The first Tanzanian Five Year Plan and the Seers mission report to $Z$ ambia, which were received at the time as quite radical documents, placed emphasis on change in the industrial structure. The strategies proposed, however, if successfully pursued, would have increased the dependence of the economies, although in new forms. The fundamental paradox of the period was that in adopting policies aimed at transforming the industrial structure through the mobilisation of foreign capital, the introduction of modern technology and the hiring of foreign management, a new pattern of dependence was being created.

That this approach had been accepted in the early years following independence was not surprising. Initially the political leadership faced the difficult challenge of taking over and staffing the colonial state. The mechanics of making the transfer, plus the need to expand the educational system, were of highest priority.

The prevailing wisdom of development economists lent support to the strategy adopted, through World Bank and other advisory reports and through the work of economic advisers. And, to be fair, even if an adviser believed in the need for a more independent strategy, he was certainly in no position to assert that need in the absence of a local political initiative.

(1) Report of the Select Committee on Unemployment, Republic of Kenya, National Assembly, December, 1970, p. 13. 
The sharp change in direction came in January, 1967, with the publication of the Arusha Declaration, by the TANU National Executive. The internal politics of TANU which led up to the Declaration would be of some interest, but the present writer has no insights, other than the explicit statements of the Declaration itself. However, certain factors evident in the economy must have played their part in preparing the ground for the Declaration.

The implementation of the Tanzania First Plan had been notably unsuccessful in implementing the ambitious targets for the mobilisation of external funds. The relative roles of private and public sector had been left ambiguous; it was becoming evident that the political and bureaucratic elites would have every opportunity to lever themselves into desirable economic positions in the private sector. However, this potential had not been realised to the point of creating a substantial and entrenched property-owning class sufficiently powerful to be an effective barrier to political change.

The two policy themes of the Arusha Declaration were socialism and self-reliance. Development of the theme of self-reliance, for example, led to the conclusion that emphasis must be placed on agriculture, on grounds somewhat close to the comparative advantage argument, which has appealed to circles outside Tanzania in which one might expect other aspects on the Declaration to be anathemas.

Nationalization initiatives followed in Zambia and Uganda. The Zambian nationalization of the copper industry involved far more substantial amounts of assets (valued at $\$ 575$ million) than those involved in the Tanzanian nationalization. The Uganda proposals were still being implemented when the coup unseated President Obote this year; nationa1ization measures are now being partially dismantled.

Export mining presents quite special characteristics, in relation in technology, marketing and management needs, which make it particularly difficult to transform a position of dependence by straightforward nationalization measures.

In general, in all the nationalizations, the acceptance of a considerable degree of continued dependence was indicated by the payment of substantial compensation and the completion of elaborate and of ten costly management agreements, often with the previous owners. The impact of the nationalization measures in creating a basis for greater independence will only be assessable as the expansion of local managerial 
capacity permits the State Corporations to end such management agreements. Also, the initial programmes are bound to reflect inherited projects. The appearance of new strategies at best will take some years.

IV THE ROLE OF THE STATE SECTOR IN ECONOMIC STRATEGY

Even in Tanzania, where the major part of the actual process of nationalisation was carried out with great dispatch, the period since has remained highly transitional in that there is a large number of immediate administrative tasks to be tackled.

Although evaluation is not yet possible, the nature of the possibilities can be demonstrated by considering two extreme models. The positive possibility is for the state sector to become a major focus for local initiatives to implement structural change and achieve a high level of development mobilisation. More able to take a longerterm view in assessing returns and more directly sensitive to social costs and externalities in economic decisionmaking, an improved development strategy becomes possible. Tactically, greater flexibility is possible as it is no longer necessary to depend on fiscal instruments or more direct controls to influence a large private sector. (1)

Of course, verbal appeals to the importance of strategy and structural change can only too easily be incantations to cloak the pursuit of the expedient or to disguise confusion of thought. Nevertheless, the experience of socialist countries indicates that there are certain characteristic advantages of the state sector, particularly in concentrating and directing energies towards the completion of a few critical tasks.

We do not need to be socialists to understand the effectiveness of this process. Indeed, Gerschenkron has attempted a generalisation that in the process of industrialisation:

(1) There is now an increasing body of evidence on the irrationalities and inefficiencies which have been endemic in the use of protection - both tariffs and quotas - and exchange controls as instruments of industrial policy in mixed economies in the less developed world. (See the OECD studies on industrialisation). Although it is possible to demonstrate that more effective policies are available, the pervasiveness of inferior policy-making might suggest certain inherent social and political inadequacies of the mixed economy as a system for development. 


\begin{abstract}
"The more backward a country's economy, the greater was the part played by special institutional factors designed to increase supply of capital to the nascent industries and, in addition, to provide them with less decentralised and better informed entrepreneurial guidance; the more backward the country, the more pronounced was the coerciveness and comprehensiveness of those factors."(1)
\end{abstract}

Gerschendron here envisages certain crucial institutional requirements, irrespective of whether the ultimate form of development consists of the development of a capitalist or socialist system. Some powerful institution must concentrate energies on crucial tasks beyond the competence of local smal1-scale enterprise, and must provide sufficient momenfum for the creation of indigenous economic enterprises capable of surviving in competition with other modern centres of development.

To elucidate our understanding further, we might examine in more detail those examples of successful growth performance that Gerschenkron, for example, has in mind. Much recent experience of state sector development in the Third World, however, has been of experiments failing. To analyse the issues facing the state sector, it might be of more value to visualise a model at the other pole from the successful role sketched in the preceding paragraphs a model of frustrated state development. For this it might be possible to draw on evidence from Ghana, Indonesia and possibly India, or Bolivia. In the Ghanai an case, for example, while the state certainly took up some part of the vocabulary of socialist development and, in the Volta project, might seem to have been attempting the sort of breakthrough which characterises successful statesponsored development, there was an extraordinary dependence upon external finance, continuing influence from foreign businessmen and an apparent confusion about economic strategy. Through the medium of short-term foreign credits, Ghana generated bankruptcy for herself and handsome returns to foreign capital goods exporters.(2) Also, in the event, the excessive dependence on foreign business to implement the Volta project meant that it did not fulfil initial

(1) Alexander Gerschenkorn, Economic Backwardness in Historical Perspective, p. 354. We may note that this formulation is politically loaded in its vocabulary; the coercion of the market had its role in the earlier industrial revolutions. (2) See Bob Fitch and Mary Oppenheimer, "Ghana: End of An Illusion", Monthly Review, July-August, 1966, pp. 120-123. 
hopes of providing the basis for substantial structural change. (1)

A sketch of frustrated state sector development in a dependent economy might be expected to have some or all of the following characteristics:-

(i) The development initiatives of the state corporations originate in crucial instances from foreign promoters.

(ii) The most obvious beneficieries of the operation of state corporations (and, in the extreme cases, the only domestic beneficiaries) are the bureaucracy.

(iii) This bureaucracy adopts the attitudes and the self-same business criteria as the foreign business people with whom they associate, while notably not being able to match their managerial performance.

(iv) Market pressures for business efficiency are reduced, yet there is no effective administrative structure to maintain effective standards of operation.

(v) In the absence of an effectively defined development strategy, project selection, even where it emanates from domestic sources, is undertaken in a piecemeal and arbitrary fashion, in many cases at a much lower level of economic rationality than under conditions of laissez faire private decisionmaking.

Where some combination of the above conditions operate, the state sector can become a great burden on the mas of the society without generating development benefits. Resources are dissipated by continuing foreign exploitation, by an ineffective but privileged bureaucratic elite, and through the high costs resulting from low levels of efficiency. When the system gets into economic trouble there is no reservoir of public support to maintain a development effort through difficult times. The poor level of economic effectiveness becomes doubly important when the political

(1) ibid. pp. 123-126. See also Ruth First, The Barrel of a Gun, London, 1970, pp. 169-190, for an interesting review of the economic record of the Nkrumah period. 
system is itself organised at a modest leve1. (1)

The importance of a coherent economic strategy for the state sector derives not only from the positive possibilities of using the state sector as an instrument for structural change, but also because in the absence of an explicitly defined source of strategy, which sets objectives and criteria for performance, the operation of the sector will depend upon a set of piecemeal initiatives. These will stem largely from private promotors who identify profitable possibilities in the operation of an expanded state sector, or from the inertia of existing, often irrelevant, business practices.

\section{$\mathrm{V}$ THE STATE SECTOR IN OPERATION}

To conclude, four areas are discussed which are strategic in determining which path the state sector follows.

(a) Relations with foreign business

The possibilities of continued involvement through the joint venture are writ large in the arrangements made in a number of cases following nationalisation. In addition to the straight profit to be made from any equity involvement, there are three means whereby the foreign investor can benefit from associating with state corporation in projects, all mentioned in the earlier part of this paper:

(i) Partnership may provide either a captive market or source of supply enabling the firm to profit at some other stage of the production process.

(ii) The pub1ic corporation may be a suitable market for machinery. Promoters may seek a profit from the capital investment in a project.

(1) And, of course, the poor bureaucratic performance may itself have its origins in an ambiguous and inappropriate political situation. See Fitch and Oppenheimer, op. cit. Shivji raises some controversial questions about the relationship between the state sector, elites and foreign economic interests in Tanzania in a piece which is probably unduly alarmist but nevertheless a healthy contribution to the prevention of the tendencies he warns against. See "The Silent Class Struggle" in the final issue of CheChe and the comments by Walter Rodney and John Saul in Maji-Maji, No. 1, January, 1971. 
(iii) The management contract and provision of consulting services provides another fertile field for foreign business activity.

In each of these cases mutually satisfactory deals can be struck by the public enterprise, providing it has honest, intelligent and skilful management. However, the potential also exists for the public enterprise to provide a tramework for deals which are even worse than the effects of unrestrained foreign investment.

The danger, in economic terms, is that the expansion of the state sector creates conditions of monopoly power, which can be used to achieve public development objectives, but which can also provide heightened opportunities for the exploitation of the local economy by foreign business, in 1 iaison with a well rewarded local group of bureaucratic intermediaries.

(b) Co-ordination

The importance of the financial decisions, and in particular the external economic relations, of key parastatals lends urgency to the need for effective control. In addition, there is an obvious danger of the employees of parastatals using their positions to create substantial privileges for themselves, at the expense of other sections of the economy. There are also the familiar, but nevertheless correct, technical planning arguments for effective co-ordination.

The extension of public ownership has located within the parastatal sector investment decisions which are, in the case of Tanzania, likely to be as large as those of the central government itself, while in Zambia they may prove to be larger.

If the capacity of the technical planning apparatus is limited and the administrative civil service has little experience of the new areas of economic decision-making opened up by the extension of the state sector, the management of the parastatals may be in a position to establish considerable autonomy.

In the abstract, it might be argued that a high degree of autonomy is no bad thing. This would be the case if an independent but effective entrepreneurial capacity were to be developed, subject of course to the need for certain minimal macroeconomic controls, and centralised 
definition of relevant performance criteria. Autonomy from local supervision can be disastrous, however, if the state corporation remains heavily dependant on external interests.

\section{(c) Relations with the domestic private sector}

The extension of public ownership has been as often a means of reinforcing capitalism as it has been of moving towards socialism. Nationalisation in a context in which one of the prime motive forces has been nationalism is especially ambiguous. The public sector could become the means of protecting and helping local private initiatives; the ranks of the bureaucracy of the public sector and government could be the recruiting ground of a generation of capitalists. Moreover, the bureaucracy itself, in some circumstances, could exercise power and enjoy, by virtue of office, privileges not dissimilar from those of a bourgeoisie.

The impact of economic policies on the relative future balance between sectors should be one explicit dimension of policy-making. One virtue of the state corporation is that it can implement projects not immediately profitable. However, when some commentators urge on the state sector a programme of unprofitable tasks leaving highly profitable, but possibly more frivolous, activities with the private sector, this may provide private investors with a ready source of surplus, the means of future growth. Thus, emphasis on infrastructural, or capital goods industry expansion in the state sector in a mixed economy can have implicit in it the "Japanese model". Fiscal devices may not provide a satisfactory method of transferring surplus from a profitable private sector to an unprofitable public corporation if the gap between the profitability of the sectors is great and the private sector remains significant in size.

\section{(d) Workers' contro1}

It may appear rather Utopian to finish this essay with a discussion of workers' control. Is workers' control a luxury, only to be indulged in when the level of productivity has risen sufficiently to run risks of inefficiency in the pursuit of other social goals? Such reactions very readily arise and incorporate legitimate doubts. In situations when the problems that management face already seem so great, it might seem foolhardy to add another complex dimension. 
However, quite apart from any virtues of industrial democracy as a social goal, it may also be seen as a means of responding to two critical problems:-

(i) A trained, professional elite only too easily become remote from the immediate problems, and potentialities of indigenous society. This not only results in a tendency for the elite to be biassed towards urban needs, but even within urban society they become insulated from the real needs of the urban masses. Only too easily elites, although formally recruited from the local population, become part of a cultural enclave almost as much apart from the board mass of the society as the previous colonial rulers.

(ii) The encouragement of workers' involvement in management facilitates the possibility of recruiting organisational and innovatory talents from amongst the workforce. It is characteristic of effective early stage economic growth (e.g. the industrial revolution under capitalism) that there is a wide field of recruitment for entrepreneurial abilities. Dependence on highly bureaucratic methods of recruitment, where the educational base is very narrow and access to it necessarily highly random, limits the range of available talent unduly, and establishes criteria for recruitment which are heavily restrictive and probably not too relevant.

The possibility of drawing on the members of the workforce for innovations and relevant adaptations of foreign technology is suggested by Chinese experience.(1) The translation of such possibilities into an African context would require the creation of a real vitality in party organisation and a positive response from the bureaucratic elite.

In their analysis Arrighi and Saul have pointed out the privileged role of the upper stratum of wage workers, who are part of the "labour aristocracy" in the emerging structures of contemporary African economies, enjoying high incomes in the limited job openings provided by highly

(1) For a critical comment on the involvement of peasants and workers in the process of technical innovation in China, see C. H. G. O1dham "Science and Education in China", Bulletin of the Atomic Scientists, June 1966, reprinted in Communist China: China Readings No. 3, (eds.) Franz Schurman and Orville Sche11, London, 1968. 
capital-intensive import substitution, with interests potentially at variance with those of the unemployed masses. masses. (1) However, it remains the case that whatever negative role this "labour aristocracy" plays within the structure of dependent economies, it must also play a key positive role in the creation of more satisfactory patterns of growth. It is amongst the more skilled workers and the bureaucratic elites that the necessary competence exists to undertake so many of the necessary tasks of economic transformation, not least of which is the creation of institutions capable of operating independently and effectively in the international economic environment.

The dilemma is a tricky one. The relatively small elite amongst the skilled workforce and the bureaucracy are needed. The maintenance of their morale and support is a necessary condition of survival. At the same time, however, as Saul has suggested, the mobilisation of popular energies, and the raising of mass consciousness is another necessary ingredient. (2)

The failure of a number of experiments in statedirected development have come when the bureaucratic elites, who were managing the system, became disaffected and moved against the political regime. Although the rhetoric of the regime associated itself with the mass of the populace, the practice of the regime alienated them, so that they acquiesced in its fall.

(1) See G. Arrighi and John S. Saul, "Nationalist and Revolution in Sub-Saharan African", in The Socialist Register, London, 1969.

(2) John S. Saul, "The Political Aspects of Independence", paper presented to the Regional African Meeting of

Development Training and Research Institutes, Nairobi, 1971. 